\title{
Prostaglandins Mediate the Vasodilatory Effect of Mannitol in the Hypoperfused Rat Kidney
}

\author{
Paul a. Johnston, David B. Bernard, Nancy S. Perrin, and Norman G. Levinsky, \\ Evans Memorial Department of Clinical Research and Department of Medicine, \\ University Hospital, Boston University Medical Center, Boston, Massachusetts \\ 02118
}

A BSTRACT We have previously reported that mannitol strikingly increases blood flow to rat kidneys hypoperfused at $35-40 \mathrm{~mm} \mathrm{Hg}$. This vasodilator effect is not due to volume expansion or alterations in plasma osmolality. We have tested the hypothesis that the vasodilatory effect of mannitol in the ischemic rat kidney is mediated by one of the vasoactive renal hormone systems: renin-angiotensin, kallikrein-kinin, or prostaglandins.

Rats were infused with $5 \%$ mannitol in $0.9 \%$ saline to $3-5 \%$ of body weight. In agreement with our previous studies, $\mathrm{RBF}$ increased $1.3 \pm 0.1 \mathrm{ml} / \mathrm{min}$ despite maintenance of perfusion pressure at $35-40 \mathrm{~mm} \mathrm{Hg}$.

The cyclooxygenase inhibitors, meclofenamate and indomethacin had no effect on renal blood flow (RBF) in hypoperfused kidneys. However, in rats pretreated with these inhibitors, expansion with mannitol increased RBF by only $0.37 \pm 0.02 \mathrm{ml} / \mathrm{min}, 28 \%$ of the response in the untreated group $(P<0.001)$. Infusion of prostacyclin $\left(\mathrm{PGI}_{2}\right)$ into the renal artery during reduced perfusion resulted in an increase in $\mathrm{RBF}$ of $1.0 \pm 0.1 \mathrm{ml} / \mathrm{min}$. Subsequent expansion with mannitol increased RBF by only $0.5 \pm 0.1 \mathrm{ml} / \mathrm{min}$ more, less than one-half of the effect of mannitol in a concurrent group of rats not treated with $\mathrm{PGI}_{2}$.

Unlike $\mathrm{PGI}_{2}$, prostaglandin $\mathrm{E}_{2}$ had only a minimal vasodilator effect during hyperperfusion. Imidazole, an inhibitor of thromboxane synthesis, did not alter RBF or renal vascular resistance during hypoperfusion.

Treatment of rats during hypoperfusion with the angiotensin-converting enzyme (kininase II) inhibitor teprotide increased RBF by $1.1 \pm 0.3 \mathrm{ml} / \mathrm{min}$. However,

Portions of this work were presented to the American Society of Nephrology in abstract form. (1979. Kidney Int. 16: 774A.)

Address reprint requests to Dr. Paul A. Johnston, University Hospital, Renal Research Laboratory, Boston, Mass. 02118.

Received for publication 29 May 1980 and in revised form 2 January 1981. teprotide did not alter the vascular response to mannitol: RBF increased $1.2 \pm 0.1 \mathrm{ml} / \mathrm{min}$ more when mannitol was infused into teprotide-treated rats.

The renal vascular response to mannitol was not altered by treatment with aprotinin, an inhibitor of the kallikrein-kinin system. Aprotinin was ineffective whether given before or after the vascular response to mannitol was established.

We conclude that the vasodilator response to mannitol in the ischemic rat kidney is mediated in large part by increased prostaglandin $\left(\mathrm{PGI}_{2}\right)$ activity. The failure of converting enzyme inhibition and aprotinin to block the vasodilator response to mannitol is evidence against a role for the renin-angiotensin or kallikreinkinin systems in mediating the vasodilator response.

\section{INTRODUCTION}

Mannitol has been widely used to prevent and treat experimental and clinical acute renal failure. The mechanisms by which it may exert a beneficial effect are uncertain. We have been studying this problem in the hypoperfused rat kidney, a model of "prerenal failure." This model seems especially suitable for determining the possible value of mannitol in preventing the development of acute renal failure in the ischemic kidney. In our previous study (1), we found that expansion with mannitol elevated renal blood flow $(\mathrm{RBF})^{1}$ and reduced renal vascular resistance (RVR) in the rat kidney perfused at a fixed pressure of 35-40 $\mathrm{mm} \mathrm{Hg}$, principally by reducing afferent arteriolar resistance. This effect correlated closely with restoration of glomerular filtration, which is absent in this model prior to treatment with mannitol $(1,2)$. The specific mechanism by which mannitol reduces RVR is

${ }^{1}$ Abbreviations used in this paper: $\mathrm{MS}, 5 \%$ mannitol in $0.9 \%$ $\mathrm{NaCl}$. PG, prostaglandin; $\mathrm{PGI}_{2}$, prostacyclin; $\mathrm{RBF}$, renal blood flow; RVR, renal vascular resistance; $R P P$, renal perfusion pressure. 
unclear from these studies. However, since comparable expansion with isotonic saline failed to reduce RVR, the effect of mannitol appears to be independent of the influence of volume expansion per se. Since isotonic mannitol also reduced RVR, changes in extracellular fluid osmolality, likewise, are not necessary to elicit a change in RVR.

The kidney contains three potent vasoactive hormone systems which appear to be important in control of renal function under a variety of physiologic conditions (3-9): the renin-angiotensin system, the kallikrein-kinin system, and the prostaglandins (PG). The purpose of the present study was to determine whether the vascular response of the hypoperfused kidney to expansion with mannitol was mediated by these vasoactive hormone systems. We have found that a substantial fraction of the effect of mannitol on RVR in the hypoperfused kidney is mediated by increased PG activity. In contrast, neither the renin-angiotensin nor kallikrein-kinin systems appear to be importantly involved in the mechanism by which mannitol vasodilates the hypoperfused kidney.

\section{METHODS}

Male Charles River (Charles River Breeding Laboratories, Wilmington, Mass.) CD rats, weighing 200-350 g, were anesthetized intraperitoneally with Ketamine $\mathrm{HCl}$ (100 $\mathrm{mg} / \mathrm{kg}$, Parke, Davis \& Co., Detroit, Mich.) and Inactin (25 $\mathrm{mg} / \mathrm{kg}$, Byk Gulden, Konstanz, West Germany). Supplemental doses of Inactin were given as needed. Body temperature was maintained between $37^{\circ}$ and $38^{\circ} \mathrm{C}$. During the control period, saline was continuously infused at $0.04 \mathrm{ml} / \mathrm{min}$ through a catheter placed in the jugular vein. Renal perfusion pressure (RPP) was monitored by means of a catheter placed in the left femoral artery and connected to a strain gauge transducer and recorder. The left renal artery was exposed through a suprapubic incision and dissected free from its attachments to the renal vein. Blood flow through the left renal artery was measured continuously with an electromagnetic flow probe (EP model 401.5) connected to a square-wave electromagnetic flowmeter (model 501, Carolina Medical Electronics, King, N. C.). Validation of this technique has been previously described (1).

After base-line measurements of RPP and RBF were obtained, RPP was reduced to $35-40 \mathrm{~mm} \mathrm{Hg}$ by means of a clamp placed around the descending aorta, $5-10 \mathrm{~mm}$ above both renal arteries. Since we have previously found that urine flow is negligible during this hypoperfusion period $(1,2)$, saline infusion was terminated to prevent excessive volume expansion. After 30-45 min of hypoperfusion, the animals were volume expanded with $5 \%$ mannitol in $0.9 \% \mathrm{NaCl}$ (MS). Perfusion pressure was maintained at $35-40 \mathrm{~mm} \mathrm{Hg}$. A volume equal to $3-5 \%$ body weight was given in $10-15 \mathrm{~min}$, followed by a continuous infusion of $M S$ at $0.1 \mathrm{ml} / \mathrm{min}$.

To determine if the renal vascular effect of MS expansion was mediated by increased renal PG synthesis, the following experiments were performed. (a) Rats were treated $15 \mathrm{~min}$ before hypoperfusion with either of the cyclooxygenase inhibitors, indomethacin or meclofenamate (10), in a dose of $2 \mathrm{mg} / \mathrm{kg}$, followed by a maintenance dose of 2 $\mathrm{mg} / \mathrm{kg}$ per h. After $30 \mathrm{~min}$ of hypoperfusion the animals were expanded with MS as described above. Since the vascular response was similar in rats treated with indomethacin or meclofenamate, the animals were subsequently considered as one group, irrespective of which inhibitor they received. (b) In a separate group of animals, we determined the effect of indomethacin $(2 \mathrm{mg} / \mathrm{kg})$ on the renal vascular response to expansion with MS at normal RPP. The protocol was identical to the first study, except that aortic clamping was omitted. (c) After 15 min of hypoperfusion, prostacyclin $\left(\mathrm{PGI}_{2}\right)$ was infused through a glass micropipette into the renal artery in a dose of $0.3-0.45 \mu \mathrm{g} / \mathrm{min}$. $\mathrm{PGI}_{2}$ was diluted in Tris buffer, $\mathrm{pH} 8.7$, and delivered at a rate of $0.01 \mathrm{ml} / \mathrm{min}$. After an additional 30 min of hypoperfusion, the rats were volume expanded with MS as described above. A control group of rats was treated in a similar manner using Tris buffer alone. $(d)$ We also assessed the effect of $\mathrm{PGE}_{2}$ on renal vascular tone during hypoperfusion. After $30 \mathrm{~min}$ of hypoperfusion, $\mathrm{PGE}_{2}, 0.5$ $\mu \mathrm{g} / \mathrm{min}$, was infused into the renal artery, while RPP was maintained at the reduced level. $\mathrm{PGE}_{2}$ was stored as a stock solution of $10 \mathrm{mg} / \mathrm{ml}$ in $95 \%$ ethanol, and subsequently diluted to desired concentrations with isotonic $\mathrm{NaCl}$ just prior to use.

To determine whether increased synthesis of thromboxanes by the hypoperfused kidney altered its RVR, six additional rats were treated with imidazole (Sigma Chemical Co., St. Louis, Mo.), a specific inhibitor of thromboxane synthesis (11). After $30 \mathrm{~min}$ of hypoperfusion, the rats were treated with either a low $(4-17 \mathrm{mg} / \mathrm{kg}$ per h) or high $(185 \mathrm{mg} / \mathrm{kg}$ per h) dose of the inhibitor dissolved in $0.9 \% \mathrm{NaCl}$ and observations of RPP and RBF were made for the next 1-h period.

To determine if the MS effect was mediated by inhibition of the renin-angiotensin system or stimulation of the kallikrein-kinin system, the following experiments were performed. (a) After 30 min of hyperperfusion rats received 250 $\mu \mathrm{g}$ of teprotide (SQ20881) intravenously. This substance inhibits the conversion of angiotensin I to angiotensin II, and potentiates the kallikrein-kinin system by inhibiting the catabolism of kinins (12). The same dose of teprotide was repeated at 30-min intervals. $10 \mathrm{~min}$ after the first dose, the animals were expanded with MS as described above. (b) Rats were treated with aprotinin (Boehringer-Mannheim Biochemicals, Indianapolis, Ind.) to inhibit kallikrein (13). A priming dose of aprotinin in $0.9 \% \mathrm{NaCl}$ equaling $15 \times 10^{3}$ kallikrein inhibitory units, was given $15 \mathrm{~min}$ before clamping the aorta, followed by an intravenous maintenance infusion of $150 \mathrm{kallikrein}$ inhibitory units $/ \mathrm{min}$ at a rate of $0.01 \mathrm{ml} / \mathrm{min}$. After $30 \mathrm{~min}$ of hypoperfusion, the rats were expanded with MS as described above. In a second series, the rats were treated with aprotinin after, rather than before, expansion with MS. The effect of this treatment on renal hemodynamics was assessed 30-40 $\mathrm{min}$ after the priming dose of aprotinin.

Time-control studies were performed in separate groups of rats to evaluate the effect of continued hypoperfusion or prolonged infusion of indomethacin, $\mathrm{PGI}_{2}$, teprotide, or aprotinin. These experiments were conducted exactly as above except that the rats were not expanded with MS.

Typically, three to five measurements of RBF were made before, and a similar number 10-60 min after each of the experimental manipulations described above. Observations before and after each maneuver were averaged to obtain a single value. Statistical probability in a group of animals each treated with several agents-e.g., hypoperfusion, $\mathbf{P G I}_{2}$, $\mathrm{PGI}_{2}$ plus MS - was determined by analysis of variance for multiple treatments in a single animal (14). Where appropriate, the means were tested by Student's $t$ test for paired observations (14). One-way analysis of variance and Dunnett's $t$ test (15) were used to determine the significance of the difference between the effect of the variance manipulations and that of mannitol. A $P<0.05$ was considered to be significant. 


\section{RESULTS}

Renal hemodynamics were assessed in 40 rats at control RPP and after 30-45 min of hypoperfusion. When RPP was reduced from $100 \pm 2$ to $37 \pm 0.3 \mathrm{~mm} \mathrm{Hg}$, RBF fell from $5.8 \pm 0.1$ to $1.3 \pm 0.1 \mathrm{ml} / \mathrm{min}(P<0.001)$, and RVR rose from $17.4 \pm 0.4$ to $30.4 \pm 1.6 \mathrm{~mm} \mathrm{Hg} / \mathrm{ml}$ per $\min (P$ $<0.001)$. These changes are similar to those of previous reports from our laboratory (1).

Table I, section A, summarizes the effect of inhibition of PG synthesis on the vascular response of the hypoperfused kidney to expansion with MS. Treatment with meclofenamate or indomethacin before hypoperfusion did not affect RBF during hypoperfusion. RBF of the rats pretreated with these inhibitors was $1.4 \pm 0.1 \mathrm{ml} / \mathrm{min}$, compared with $1.6 \pm 0.1 \mathrm{ml} / \mathrm{min}$ for nontreated animals. Subsequent expansion with MS increased $R B F$ by only $0.37 \pm 0.02 \mathrm{ml} / \mathrm{min}$ in rats treated with either of the inhibitors. This change in RBF was significantly less than that caused by MS in the control group of rats studied concurrently, $1.3 \pm 0.1 \mathrm{ml} / \mathrm{min}(P<0.001$, treated vs. nontreated).

TABLE I

Relation of Renal PG to Mannitol-induced Vasodilation during Hypoperfusion

\begin{tabular}{ccc}
\hline RBF & RVR \\
\hline $\mathrm{ml} / \mathrm{min}$ & $\mathrm{mm} \mathrm{Hg} / \mathrm{ml} / \mathrm{min}$
\end{tabular}

A Effect of cyclooxygenase

inhibition during

hypoperfusion

Nontreated $(n=9)$

Control

Mannitol

$1.6 \pm 0.1$

$23.9 \pm 1.5$

$2.9 \pm 0.2^{*}$

$13.5 \pm 0.7 *$

Inhibitor-treated ( $n=6)$

PG inhibition

Mannitol

$1.4 \pm 0.1$

$27.2 \pm 1.9$

$1.8 \pm 0.1$

$21.9 \pm 1.5$

B Effect of indomethacin or meclofenamate at normal RPP

Nontreated $(n=8)$

Control

Mannitol

Inhibitor-treated $(n=4)$

PG inhibition

Mannitol

C Effect of $\mathrm{PGI}_{2}$ during

hypoperfusion $(n=5)$

Control

$\mathrm{PGI}_{2}$

$\mathrm{PGI}_{2}$ plus mannitol
RBF and RVR of the hypoperfused kidney remained unchanged for $1 \mathrm{~h}$ during treatment with imidazole, a specific inhibitor of the synthesis of thromboxanes, which are potent vasoconstrictors. RBF after 30 min of hypoperfusion was $1.2 \pm 0.1 \mathrm{ml} / \mathrm{min}$, and $1.3 \pm 0.2$ $\mathrm{ml} / \mathrm{min}$ after $1 \mathrm{~h}$ of imidazole infusion $(n=6)$. Corresponding values for $R V R$ were $33.8 \pm 2.6$ and $32.1 \pm 2.9$ $\mathrm{mm} \mathrm{Hg} / \mathrm{ml}$ per min.

We also assessed the response of the renal vasculature at normal perfusion pressure to expansion with MS in indomethacin-treated and nontreated rats. (Table I, section B). Expansion with MS resulted in an increase in RBF of $1.2 \pm 0.5 \mathrm{ml} / \mathrm{min}$, and a fall in RVR of $3.0 \pm 1.1$ $\mathrm{mm} \mathrm{Hg} \mathrm{ml} \mathrm{per} \mathrm{min} \mathrm{in} \mathrm{nontreated} \mathrm{animals.} \mathrm{In} \mathrm{the} \mathrm{indo-}$ methacin-treated animals, RBF rose $2.1 \pm 0.9 \mathrm{ml} / \mathrm{min}$, and RVR fell $3.4 \pm 1.4 \mathrm{~mm} \mathrm{Hg} / \mathrm{ml}$ per min. These changes were not statistically different from those observed in the nontreated group.

Table I, section C, summarizes the effect of infusion of $\mathrm{PGI}_{2}$ on renal hemodynamics during hypoperfusion and subsequent expansion with MS. Infusion of $\mathrm{PGI}_{2}$ into the renal artery after $15 \mathrm{~min}$ of hypoperfusion increased RBF by $1.0 \pm 0.1 \mathrm{ml} / \mathrm{min}(P<0.005)$. This effect of $\mathbf{P G I}_{2}$ was not significantly different from that caused by expansion with MS, $1.3 \pm 0.1 \mathrm{ml} / \mathrm{min}$, in a separate, concurrent series of rats. Subsequent expansion with MS increased RBF by only $0.5 \pm 0.1 \mathrm{ml} / \mathrm{min}$ in rats pretreated with $\mathrm{PGI}_{2}$. This additional effect of MS was significantly less than its effect in the concurrent series of rats not treated with indomethacin $(P<0.001)$. Infusion of Tris buffer (the vehicle for $\mathrm{PGI}_{2}$ ) alone had no effect on RBF or on the response to expansion with MS $(n=5)$.

The left-hand bars of Fig. 1 compare the effects of MS, PG inhibition, and $\mathrm{PGI}_{2}$ infusion on RBF in the hypoperfused kidney. PG inhibition, although it had no direct effect on $R B F$, decreased the renal vascular response to $\mathrm{MS}$ expansion to $\sim 28 \%$ of the response in nontreated rats. $\mathrm{PGI}_{2}$ increased $\mathrm{RBF}$ by nearly as much as expansion with MS alone. The effect of subsequent

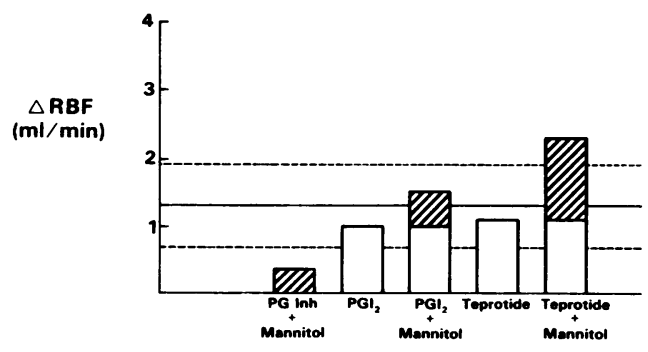

FIGURE 1 Summary of changes in RBF during hypoperfusion. Solid and dashed horizontal lines represent the mean \pm 2 SD change in RBF caused by MS expansion alone. Cross-hatched bars represent the mean effect of MS expansion during various experimental manipulations. Open bars represent the mean effect of $\mathrm{PGI}_{2}$ or teprotide. 
expansion with MS was significantly blunted by pretreatment with $\mathrm{PGI}_{2}$. The total vasodilatory effect of $\mathrm{PGI}_{2}$ plus MS was not different from the effect of MS expansion in nontreated rats.

We also assessed the response of the renal vasculature to $\mathrm{PGE}_{2}$ infused into the renal artery during hypoperfusion $(n=5)$. $\mathrm{PGE}_{2}$ infusion increased RBF by only $0.16 \pm 0.05 \mathrm{ml} / \mathrm{min}$. This change was significant $(P<0.05)$, but was significantly less $(P<0.001)$ than the increase in $\mathrm{RBF}$ caused by $\mathrm{PGI}_{2}, 1.0 \pm 0.1 \mathrm{ml} / \mathrm{min}$, reported above.

Table II summarizes the effect of converting enzyme (kininase II) inhibition on the hemodynamics of the hypoperfused kidney, and on the response to subsequent expansion with MS. In 18 rats, teprotide increased RBF by $1.1 \pm 0.3 \mathrm{ml} / \mathrm{min}(P<0.001)$. Subsequent expansion with MS resulted in a further increase in RBF of $1.2 \pm 0.1 \mathrm{ml} / \mathrm{min}$ (Fig. 1), a value not significantly different from the effect of mannitol alone (see Table I). As shown in the two right-hand bars of Fig. 1, the combined effect of teprotide and MS expansion was additive and significantly greater than that of MS expansion alone $(P<0.001)$. Despite maintenance of a greatly reduced RPP, the combined vasodilator effect of these two agents increased RBF to $3.4 \pm 0.1 \mathrm{ml} / \mathrm{min}$ (Table II). This is 2.5 times the usual value for $R B F$ at $R P P$ of $40 \mathrm{~mm} \mathrm{Hg}$, and $57 \%$ of the RBF at normal RPP in the anesthetized rat (Table I).

Table III summarizes the effect of aprotinin treatment on the renal vascular response to expansion with MS. Aprotinin had no direct effect on RBF during hypoperfusion; compare the RBF of $1.4 \pm 0.1 \mathrm{ml} / \mathrm{min}$ in part $\mathrm{A}$ of the table to that for hypoperfusion alone, $1.5 \pm 0.1 \mathrm{ml} / \mathrm{min}$, in part B. After treatment with aprotinin, MS expansion increased RBF by $0.91 \pm 0.09 \mathrm{ml} /$ min (Table III, A). This effect of MS was not different from that of MS expansion in a concurrent series of four rats not treated with aprotinin, $1.1 \pm 0.1 \mathrm{ml} / \mathrm{min}$ (Table III, B). In addition, aprotinin, when given after the vascular response to MS expansion was fully established, did not reverse this effect (Table III, B).

TABLE II

Effect of Inhibition of Converting Enzyme (Kininase II) on Hemodynamics of the Hypoperfused Kidney

\begin{tabular}{lcl}
\hline & RBF & \multicolumn{1}{c}{ RVR } \\
\hline & $\mathrm{ml} / \mathrm{min}$ & $\mathrm{mm} \mathrm{Hg} / \mathrm{ml} / \mathrm{min}$ \\
& $1.1 \pm 0.1$ & $40.8 \pm 2.4$ \\
Hypoperfusion $(n=18)$ & $2.4 \pm 0.1^{*}$ & $18.3 \pm 1.4^{*}$ \\
Teprotide $(n=18)$ & $3.4 \pm 0.1^{*} \neq$ & $11.3 \pm 0.5^{*}$ \\
Teprotide plus mannitol $(n=6)$ &
\end{tabular}

Data are mean $\pm \mathrm{SE}$.

$* P<0.001$ vs. hypoperfusion.

$\neq P<0.001$ vs. teprotide.
TABLE III

Effect of Aprotinin on Vascular Response of Hypoperfused Kidney to Mannitol

\begin{tabular}{|c|c|c|c|}
\hline & & RBF & RVR \\
\hline & & $\mathrm{ml} / \mathrm{min}$ & $\mathrm{mm} \mathrm{Hg} / \mathrm{ml} / \mathrm{min}$ \\
\hline \multirow[t]{3}{*}{ A } & $\begin{array}{c}\text { Aprotinin given before } \\
\text { mannitol }(n=5)\end{array}$ & & \\
\hline & Aprotinin & $1.4 \pm 0.1$ & $28.8 \pm 0.7$ \\
\hline & Aprotinin plus mannitol & $2.3 \pm 0.1 *$ & $18.5 \pm 1.0^{*}$ \\
\hline \multirow[t]{4}{*}{ B } & $\begin{array}{l}\text { Aprotinin given after } \\
\text { mannitol }(n=4)\end{array}$ & & \\
\hline & Hypoperfusion & $1.5 \pm 0.1$ & $26.4 \pm 2.8$ \\
\hline & Mannitol & $2.5 \pm 0.1 \neq$ & $15.3 \pm 0.8 \S$ \\
\hline & Mannitol plus aprotinin & $2.5 \pm 0.1 \ddagger$ & $14.7 \pm 0.9 \S$ \\
\hline
\end{tabular}

Data are mean $\pm \mathrm{SE}$.

$* P<0.001$ vs. aprotinin.

$\$ P<0.001$ vs. hypoperfusion.

$\S P<0.025$ vs. hypoperfusion.

The effect of time on RBF and RVR was observed in rats undergoing hypoperfusion alone or during prolonged treatment with indomethacin, $\mathbf{P G I}_{2}$, teprotide, or aprotinin. Continued hypoperfusion had no significant effect on RBF or RVR. After 30 min of hypoperfusion, RBF was $1.5 \pm 0.2 \mathrm{ml} / \mathrm{min}$ and RVR was $27.1 \pm 3.1$ $\mathrm{mm} \mathrm{Hg} / \mathrm{ml}$ per $\min (n=7)$. After $1.5-2 \mathrm{~h}$ of hypoperfusion, RBF was $1.3 \pm 0.2 \mathrm{ml} / \mathrm{min}$ and RVR was 29.3 $\pm 3.3 \mathrm{~mm} \mathrm{Hg} / \mathrm{ml}$ per min. Indomethacin had no effect on RBF or RVR during the lst $h$ of infusion. RVR fell slightly but significantly $(P<0.05)$ during the subsequent $30-60-\mathrm{min}$ period. RBF was $1.3 \pm 0.1 \mathrm{ml} / \mathrm{min}$ $5 \mathrm{~min}$ after beginning hypoperfusion, $1.6 \pm 0.2 \mathrm{ml} / \mathrm{min}$ after $60 \mathrm{~min}$, and $1.5 \pm 0.1 \mathrm{ml} / \mathrm{min}$ after $90-120 \mathrm{~min}$. RVR was $30.7 \pm 2.0 \mathrm{~mm} \mathrm{Hg} / \mathrm{ml}$ per min $5 \mathrm{~min}$ after beginning hypoperfusion, $27.6 \pm 3.3 \mathrm{~mm} \mathrm{Hg} / \mathrm{ml}$ per min after $60 \mathrm{~min}$, and $26.2 \pm 3.3 \mathrm{~mm} \mathrm{Hg} / \mathrm{ml}$ per min after 90-120 $\min (n=4)$. $\mathrm{PGI}_{2}$ vasodilated the hypoperfused kidney during the 1st $30 \mathrm{~min}$ of infusion; there was a tendency toward further reduction in RVR during the subsequent $60-90 \mathrm{~min}$, but this was not statistically significant. RBF was $1.5 \pm 0.2 \mathrm{ml} / \mathrm{min}$ during hypoperfusion and rose to $2.3 \pm 0.1 \mathrm{ml} / \mathrm{min}$ after $30 \mathrm{~min}$ of $\mathrm{PGI}_{2}$ infusion $(n=4)$. Corresponding values for RVR were $33.7 \pm 5.3 \mathrm{~mm} \mathrm{Hg} / \mathrm{ml}$ per $\mathrm{min}$ and $17.8 \pm 1.5 \mathrm{~mm} \mathrm{Hg} / \mathrm{ml}$ per min. After a further $60-90 \mathrm{~min}$ of $\mathrm{PGI}_{2}$ infusion, RBF was $3.1 \pm 0.4 \mathrm{ml} / \mathrm{min}$ and RVR was $13.8 \pm 1.9 \mathrm{~mm}$ $\mathrm{Hg} / \mathrm{ml}$ per min. There was a tendency for $\mathrm{RBF}$ to fall and for RVR to rise throughout prolonged aprotinin infusion. RBF was $1.7 \pm 0.1 \mathrm{ml} / \mathrm{min}$ after $30 \mathrm{~min}, 1.6$ $\pm 0.1 \mathrm{ml} / \mathrm{min}$ after $60 \mathrm{~min}$, and $1.4 \pm 0.1 \mathrm{ml} / \mathrm{min}$ after 90-120 $\min (n=4)$. Corresponding RVR was 24.0 $\pm 2.0 \mathrm{~mm} \mathrm{Hg} / \mathrm{ml}$ per $\mathrm{min}, 24.1 \pm 2.3 \mathrm{~mm} \mathrm{Hg} / \mathrm{ml}$ per min, and $30.1 \pm 1.6 \mathrm{~mm} \mathrm{Hg} / \mathrm{ml}$ per min. Finally, in four rats treated with teprotide, RBF and RVR did not change between 30 and 120 min after treatment was begun. 
$\mathrm{RBF}$ was $2.2 \pm 0.4 \mathrm{ml} / \mathrm{min}$ after $30 \mathrm{~min}$ and $2.4 \pm 0.6 \mathrm{ml} /$ min after 90-120 min. Corresponding values for RVR were $17.0 \pm 2.0 \mathrm{~mm} \mathrm{Hg} / \mathrm{ml}$ per min and $16.7 \pm 3.2 \mathrm{~mm}$ $\mathrm{Hg} / \mathrm{ml}$ per min.

\section{DISCUSSION}

As in our previous study (1), volume expansion with MS resulted in a significant elevation in RBF and reduction in RVR in rat kidneys perfused at a fixed pressure of $35-40 \mathrm{~mm} \mathrm{Hg}$. When rats were treated with either indomethacin or meclofenamate to block PG synthesis, the vascular response to expansion with MS was significantly reduced. Moreover, the response to MS expansion was greatly blunted when kidneys were initially vasodilated by infusion of $\mathrm{PGI}_{2}$ (Table I). In contrast, the vascular effect of MS expansion was not altered by manipulation of the renin-angiotensin or kallikrein-kinin systems. Teprotide (SQ20881) blocks the renal vasoconstrictor effect of the renin-angiotensin system by inhibiting conversion of angiotensin I to angiotensin II. It potentiates the vasodilator effect of the kallikrein-kinin system by inhibiting degradation of kinins (12). Teprotide failed to alter the vascular response to MS expansion even though this substance when given alone increased RBF nearly as much as expansion with MS (Table II, Fig. 1). ${ }^{2}$ In animals treated with the kallikrein inhibitor aprotinin, to block kinin production, MS expansion increased RBF to the same extent as in nontreated animals (Table III). From these observations, we concluded that the hemodynamic response of the hypoperfused kidney to MS expansion is mediated principally by stimulation of PG synthesis. Stimulation of kinin production and inhibition of angiotensin II do not appear to be important mechanisms in the vascular response of the hypoperfused kidney to MS expansion.

$\mathrm{PGI}_{2}$ infusion during hypoperfusion resulted in a significant elevation in $\mathrm{RBF}$, while vasodilation in response to $\mathrm{PGE}_{2}$, although statistically significant, was minimal. $\mathrm{PGI}_{2}$ has been shown to be the major endproduct of arachidonic acid metabolism in vascular tissues (18), and a more potent vasodilator than $\mathrm{PGE}_{2}$ in rats and rabbits $(8,9)$. In fact, some investigators have found that $\mathrm{PGE}_{2}$ causes vasoconstriction in rats and rabbits $(9,19,20)$. In addition, Whorton et al. (21)

\footnotetext{
${ }^{2}$ Recent observations in rabbits (16) and man (17) suggest that an increase in PG may mediate part of the vasodilatory effect of converting enzyme inhibitors. It is possible that increased PG activity may account for part of the vasodilator effect of teprotide in our experiments. However, the failure of prior teprotide treatment to attenuate vasodilation by mannitol argues against this. Teprotide may not stimulate PG in the hypoperfused rat kidney or it may increase only $\mathrm{PGE}_{2}$, which is not an effective renal vasodilator.
}

and Fitzpatrick et al. (22) have shown that $\mathrm{PGI}_{2}$ is made by the renal cortex and may account for most of the renal vasodilator effects of arachidonic acid metabolism in dog and rabbit. Whereas $\mathrm{PGE}_{2}$ failed to cause vasoconstriction in our studies, the renal vasculature of the hypoperfused kidney appeared to be much less sensitive to infusion of $\mathrm{PGE}_{2}$ than $\mathrm{PGI}_{2}$. These observations suggest that $\mathrm{PGI}_{2}$, rather than $\mathrm{PGE}_{2}$, is probably the specific PG mediating the vasodilatory effect of MS expansion.

We also considered the possibility that MS expansion might be causing renal vasodilation by inhibiting the production of thromboxanes, end-products of arachidonic acid metabolism with vasoconstrictor properties $(23,24)$. This possibility seems unlikely, however, because treatment with imidazole, which blocks thromboxane production, did not result in vasodilation of the hypoperfused kidney.

A possible alternative explanation of our data is that mannitol enhances the vascular responsiveness to PG, which are elevated because of hypoperfusion. Support for this interpretation comes from the observation that PGE-like material in the renal vein of the dog is increased by hypoperfusion (25-27). Under these conditions in the dog, inhibition of cyclooxygenase markedly increases RVR (26-28). The failure of cyclooxygenase inhibitors to increase RVR in our experiments (Table I, A) argues against a high level of PG activity in the rat kidney perfused at $40 \mathrm{~mm} \mathrm{Hg}$. These observations agree with those of other investigators $(9,29)$, who report that cyclooxygenase inhibition has no effect on RVR in the rat at normal or moderately reduced RPP. Nevertheless, the possibility that $P G$ are elevated in the ischemic rat kidney and that mannitol acts, not by stimulating production, but by overcoming vascular resistance to these hormones, can only be ruled out by direct measurement of $\mathrm{PGI}_{2}$ production. We were unable to directly measure $\mathrm{PGI}_{2}$ production in this study. $\mathrm{PGI}_{2}$ itself is very unstable, and its metabolism is usually monitored by measurement of its more stable byproducts. In the rat, as many as seven metabolites of $\mathrm{PGI}_{2}$ are produced, the major ones being diketo derivatives $(30,31)$. Hence, although our data strongly suggest that mannitol stimulates $\mathrm{PGI}_{2}$ synthesis or release in the hypoperfused kidney, they are not unequivocal proof.

The fact that the vascular response to MS expansion was not completely eliminated by inhibition of PG synthesis or by prior administration of $\mathrm{PGI}_{2}$ may be explained by one of several possibilities. First, Zambraski and Dunn (32) have recently demonstrated that meclofenamate and indomethacin to not block PG synthesis completely. Doses of these inhibitors, similar to those used in this study, inhibited secretion and excretion of $\mathrm{PGE}_{2}$ by only $65-86 \%$. This is one likely explanation for the observation that these inhibitors 
blocked only $\sim 70 \%$ of the vascular effect of MS expansion in our studies. Second, our time-control studies indicate a tendency for modest further vasodilation during prolonged infusion of $\mathrm{PGI}_{2}$ and cyclooxygenase inhibitors. It is possible, therefore, that part of the residual response to MS in rats treated with these agents was actually the effect of extended infusions of the agents rather than a response to MS itself. Third, a small portion of the vasodilatory effect of MS expansion may be mediated by non-PG mechanisms. It has been previously suggested that changes in viscosity and hematocrit following MS expansion could account for a small part of the increase in $\operatorname{RBF}(2,33)$. It is possible that the small increase in RBF that occurred in response to MS expansion during blockade of PG synthesis was the result of such a change in the physical properties of the blood. Fourth, there might be some minimum value for RVR at an RPP of 40 $\mathrm{mm} \mathrm{Hg}$. It might be argued, in the case of $\mathrm{PGI}_{2}$ infusion, that the initial vasodilation caused by this PG may have limited the vascular response to mannitol, not because of an interaction with the PG, but simply because the absolute physical limit for vasodilation had been reached. The results of the experiments with teprotide indicate that this is probably not the case. Initial vasodilation with this agent did not prevent full expression of the vasodilator effect of mannitol. Thus, the effect of $\mathrm{PGI}_{2}$ is specific, rather than a more generalized response which would be true of any vasodilator.

We were interested in determining whether the PG system might mediate the vasodilator effect of MS expansion on the renal vasculature at normal RPP. RBF rose and RVR fell $\sim 20 \%$ in the normally perfused rat kidney in response to our standard MS expansion (Table I). Blockade of PG synthesis failed to reduce the response to MS expansion. This suggests that enhanced PG synthesis is probably not an important part of the mechanism by which mannitol can vasodilate the kidney at normal RPP. It is worth emphasizing that the vascular response of severely hypoperfused kidney to vasoactive agents other than mannitol also may differ significantly from that of the normally perfused kidney. Kinins, acetylcholine, papaverine (1), and furosemide (unpublished data), all potent dilators at normal RPP, are ineffective in the hypoperfused kidney.

In summary, we conclude that the renal vascular response to MS expansion during hypoperfusion is mediated, in large part, by an interaction with the renal PG system. The likeliest explanation is that increased $\mathrm{PGI}_{2}$ activity mediates this vasodilator response. Studies in other laboratories have provided evidence that treatment with either mannitol $(1,2)$ or PG $(34)$ may decrease renal insufficiency in a number of models of acute renal failure. Our results suggest that both agents may act, in part, by common vascular mechanisms under those circumstances as well as in the hypoperfused kidney.

\section{ACKNOWLEDGMENTS}

The authors acknowledge the secretarial assistance of Ms. Valerie Worrell and Ms. Ann Schmidt. $\mathrm{PGI}_{2}$ and $\mathrm{PGE}_{2}$ used in this study were supplied by Dr. John Pike, Upjohn Co., Kalamazoo, Mich.

These studies were supported by National Institutes of Health grant HL-22172.

\section{REFERENCES}

1. Johnston, P. A., D. B. Bernard, J. F. Donohoe, N. S. Perrin, and N. G. Livinsky. 1979. Effect of volume expansion on hemodynamics of the hypoperfused rat kidney. J. Clin. Invest. 64: 550-558.

2. Morris, C. R., E. A. Alexander, F. J. Bruns, and N. G. Levinsky. 1972. Restoration and maintenance of glomerular filtration by mannitol during hypoperfusion of the kidney. J. Clin. Invest. 51: 1555-1564.

3. Schambelan, M., and J. R. Stockigt. 1979. Pathophysiology of the renin-angiotensin system. In Contemporary Issues in Nephrology. Hormonal Function and The Kidney. B. M. Brenner and J. H. Stein, editors. Churchill Livingstone, New York. 4: 1-39.

4. Margolius, H. S., and J. B. Buse. 1979. The renal kallikrein-kinin system. In Contemporary Issues in Nephrology. Hormonal Function and The Kidney. B. M. Brenner and J. H. Stein, editors. Churchill Livingstone, New York. 4: $115-145$.

5. Dunn, M. J. 1979. Renal prostaglandins: influences on excretion of sodium and water, the renin-angiotensin system, renal blood flow, and hypertension. In Contemporary Issues in Nephrology. B. M. Brenner and J. H. Stein, editors. Churchill Livingstone, New York. 4: 89-114.

6. Navar, L. G., and H. A. Langford. 1974. Effects of angiotensin on the renal circulation. In Angiotensin. I. H. Page and F. M. Bumpus, editors. Springer-Verlag, New York. 455- 474.

7. Baylis, C., W. M. Deen, B. D. Myers, and B. M. Brenner. 1976. Effect of some vasodilator drugs on transcapillary fluid exchange in the renal cortex. Am. J. Physiol. 230: 1148-1158.

8. Armstrong, J. M., N. Lattimer, S. Moncada, and J. R. Vane. 1978. Comparison of the vasodepressor effects of prostacyclin and 6-oxo-prostaglandin $\mathrm{F}_{1 \alpha}$ with those of prostaglandin $\mathrm{E}_{2}$ in rats and rabbits. Br. J. Pharmacol. 62: $125-138$.

9. Gerber, J. G., and A. S. Nies. 1979. The hemodynamic effects of prostaglandin in the rat. Evidence for important species variation in renovascular response. Circ. Res. 44: 406-410.

10. Flower, R. J. 1974. Drugs which inhibit prostaglandin biosynthesis. Pharmacol. Rev. 26: 33-67.

11. Moncada, S., S. Bunting, K. Mullane, P. Thorogood, R. J. Vane, A. Raz, and P. Needleman. 1977. Imidazole: a selective inhibitor of thromboxane synthetase. Prostaglandins. 13: 611-618.

12. Cheung, H. S., and D. W. Cushman. 1973. Inhibition of homogenous angiotensin-converting enzyme of rabbit lung by synthetic venom peptides of Bothrops jararaca. Biochem. Biophys. Acta. 293: 451-463.

13. Werle, E., F. Fiedler, and H. Fritz. 1973. Recent studies 
on kallikreins and kallikrein inhibitors. In Pharmacology and the Future of Man. Proc. Int. Congr. Pharmacology. Karger, Basel Switzerland. 284-295.

14. Winer, B. J. 1962. Statistical Principles in Experimental Design. McGraw-Hill Book Co., Inc., New York. 306-312.

15. Dunnett, C. W. 1955. A multiple comparison procedure for comparing several treatments with control. J. Am. Statist. Assoc. 50: 1096-1121.

16. Murthy, V. S., T. L. Waldron, and M. E. Goldberg. 1975. The mechanism of bradykinin potentiation after inhibition of angiotensin-converting enzyme by SQ14225 in conscious rabbits. Circ. Res. 43(Suppl. I): 40-45.

17. Swartz, S. L., G. H. Williams, N. K. Hollenberg, L. Levine, R. G. Dluhy, and T. J. Moore. 1980. Captoprilinduced changes in prostaglandin production. Relationships to vascular responses in normal man.J. Clin. Invest. 64: $1257-1264$.

18. Moncada, S., and J. R. Vane. 1979. The role of prostacyclin in vascular tissue. Fed. Proc. 38: 66-71.

19. Malik, K. U., and J. C. McGiff. 1975. Modulation by prostaglandins of adrenergic transmission in the isolated perfused rabbit and rat kidney. Circ. Res. 36: 599-609.

20. Malik, K. U., P. Ryan, and J. C. McGiff. 1976. Modification by prostaglandins $E_{1}$ and $E_{2}$, indomethacin, and arachidonic acid of the vasoconstrictor responses of the isolated perfused rabbit and rat mesenteric arteries to adrenergic stimuli. Circ. Res. 39: 163-167.

21. Whorton, A. R., M. Smigel, J. A. Oates, and J. C. Frolich. 1978. Regional differences in prostaglandin formation by the kidney. Prostacyclin is a major prostaglandin of renal cortex. Biochim. Biophys. Acta. 529: 176-180.

22. Fitzpatrick, T. M., I. Alter, E. J. Corey, P. W. Ramwell, J. C. Rose, and P. A. Kot. 1978. Cardiovascular responses to $\mathrm{PGI}_{2}$ (prostacyclin) in the dog. Circ. Res. 42: 192- 194.

23. Morrison, A. R., K. Nishikawa, and P. Needleman. 1978. Thromboxane $\mathrm{A}_{2}$ biosynthesis in the ureter obstructed isolated perfused kidney of the rabbit. J. Pharmacol. Exp. Ther. 205: 1-8.

24. Yarger, W. E., D. D. Schocken, and R. H. Harris. 1980.
Obstructive nephropathy in the rat. Possible roles for the renin-angiotensin system, prostaglandins, and thromboxanes in postobstructive renal function. J. Clin. Invest. 65: $400-412$.

25. McGiff, J. C., K. Crowshaw, N. A. Terragno, A. S. Lonigro, J. C. Strand, N. A. Williamson, J. B. Lee, and K. K. F. Ng. 1970. Prostaglandin-like substances appearing in canine venous blood during renal ischemia. Circ. Res. 7: 765782 .

26. Johnston, P. A., and E. E. Selkurt. 1976. Effect of hemorrhagic shock on renal release of prostaglandin $\mathrm{E}$. Am. J. Physiol. 230: 831-838.

27. Satoh, S., and B. G. Zimmerman. 1975. Influence of the renin-angiotensin system on the effect of prostaglandin synthesis inhibitors in the renal vasculature.Circ. Res. 36, 37(Suppl. I): 89-96.

28. Kaloyanides, G. J., R. E. Ahrens, J. A. Shepard, and G. F. Di Bona. 1976. Inhibition of prostaglandin $E_{2}$ secretion. Failure to abolish autoregulation in the isolated dog kidney. Circ. Res. 38: 67-73.

29. Finn, W. F., and W. J. Arendshorst. 1976. Effect of prostaglandin synthetase inhibitors on renal blood flow in the rat. Am. J. Physiol. 231: 1541-1545.

30. McGuire, J. C., and F. F. Sun. 1978. Metabolism of prostacyclin: oxidation by Rhesus monkey lung of 15hydroxyl prostaglandin dehydrogenase. Arch. Biochem. Biophys. 189: 92-96.

31. Sun, F. F., and B. M. Taylor, 1978. Metabolism of prostacyclin in the rat. Biochemistry. 17: 4096-4101.

32. Zambraski, E. S., and M. J. Dunn. 1979. Renal prostaglandin $\mathrm{E}_{2}$ secretion and excretion in conscious dog. Am. J. Physiol. 236: F552-F558.

33. Lilien, O. M., S. G. Jones, and C. B. Mueller. 1963. The mechanism of mannitol diuresis. Surg. Gynecol. Obstet. 117: 221-228.

34. Mauk, R. H., R. V. Patak, S. Z. Fadem, M. D. Lifschitz, and J. H. Stein. 1977. Effect of prostaglandin $E$ administration in a nephrotoxic and a vasoconstrictor model of acute renal failure. Kidney Int. 12: 122-130. 